\title{
Patriarch Filotei I Kokkinos and the Western Church
}

\section{Marius TELEA*}

Abstract: Patriarch Filotei I Kokkinos and the Western Church. Patriarch Philotheus I was one of the greatest Byzantine names and one of the brightest, through its multiple forms in which he excelled. Man with a thorough and extensive theological and secular culture, author of works as diverse and extensive as valuable, living in prayer and holiness, he was a bishop with joint responsibility and with an unmatched authority.

His action and philosophical thinking, prayer and hesychastic contemplation, his energy to impose the clericals morality, his Orthodox conscience and his Hellenism, his intransigence toward Churches union only for political reasons, the visionary man imposing the Byzantine Church as a force truly ecumenical in order to save the Empire, all but also others met in the one who was Philotheus I Kokkkinos.

Keywords: Philotheus I, hesychasm, Churches union, authority.

\footnotetext{
* PhD Associate Professor, Faculty of Orthodox Theology at "1 Decembrie 1918" University of Alba Iulia, Romania; last work: „The Phenomenon of Pilgrimage in the Byzantine World”, în vol. Simpozionului științific internațional „Communication, Context, Interdisciplinarity. Convergent Discourses. Exploring the Contexts of Communication", 4-th Edition (CCI 4), Târgu Mureș, 20-21 octombrie 2016, Secțiunea: History and Cultural Mentalities, editori: Iulian BOLDEA, Dumitru-Mircea BUDA, Târgu Mureș, Arhipelag XXI Press, 2016, pp. 159-166.
} 


\section{Preliminaries}

Patriarch with a strong personality, with his own political vision and initiative man, senior scholar and fecund writer, Filothei I Kokkinos (1353-1354; 1364-1376) was one of the greatest Byzantine names and one of the brightest. While the political power was decaying in the Byzantine Empire, culture and religion began to flourish, showing the greatness of the Eastern Roman Empire across its borders. Orthodoxy, in Byzantium, asserted itself by the hesychasm, explaining the uncreated character of the light and the divine energies. It was not limited only to doctrinal explanations and monastic practices, but it made an entire improvement among church ministers. The patriarch Filotei I Kokkinos was the one who involved the hesychasm in serving the Byzantine national ideals, understanding that the political hesychasm was the only hope for the rescue of the Byzantine Empire, which could no longer be saved by military means. The hesychasts have raised monastic and clerical morality so much that, through their harsh and anti-formalism living, they have imposed respect both in the Byzantine Church and throughout Orthodoxy. Emperor Ioan VI of Cantacuzino (1341-1354) was the one who promoted the hesycasts in the van of the Church, who proved during the time that they were spiritual and genuine intellectuals. Although the patriarch Filothei I Kokkinos is not well-known to us, being often overlooked by the historical research, he remains a strong personality who had his own political initiatives, independent of the emperor's, a thorough and profound theological and laic culture, being a perfect patriarch whose name can sit near with the patriarchs Fotie and Mihail Cerularie.

\section{Filothei's anti-unionist attitude}

The restoration of Christian unity was a very important problem in the 14th century. And if Emperor Ioan V Paleologul (1341-1391) has put all his hopes in the association with Rome, it is also obvious that Ioan VI of Cantacuzino all his life has been 


\section{Patriarch Filotei I Kokkinos and the Western Church}

concerned about the issue of church unification ${ }^{1}$. If the negociations between Constantinople, Avignon, or Rome throughout this age did nothing, it was not because of the lack of interest or enthusiasm of those who initiated or carried them, but because of the fact that they always wanted to materialize in military help for Byzantium and the imposition of papal supremacy. And these interests being the real ones, the honest thought of Christian unity has never been the basis of the negotiations. The unification was treated as a strictly political issue, and the Byzantine Church was now the least interested in union, being hostile indeed. The Emperor who struggled to make the unification could no longer decide in the church's issues as his forefathers.

Ioan $\mathrm{V}$ wanted to associate to Rome a church that did not want the union, and he was too weak to kneel this church now that the patriarch Filotei I was in the van of it. Many were the attempts of church unification, but the obstacles were great, and everything was a waste of energy. Byzantium went towards a disaster, and nothing could stop it. Reaching an extremely small territory and threatened by the total collapse under the Turks, a reality at which the neighboring Christian states have contributed to, many saw the only possibility of saving the church unification. But things were so complicated that the salvation through unification was an illusion, as it turned out to be. In Byzantium, a great need for military aid overpowered the papal support and pope's authority over Catholic principles. Rome wanted the imposing of the supremacy over the Orthodox Church and overestimated the role of the emperor in this respect. The Byzantine world stored hatred against the Latins, the memory of 1204 being still awake, and the Latins had the same feeling about the Byzantines. The disregard was mutual.

Both Churches were convinced by the schism and heresy of the other. With all the goodwill of Ioan Cantacuzino and of IoanV Paleologul or of Pope Clement VI (1342-1352), Inocențiu VI (1352-1362) or Urban V (1362-1370), the reality of a king or

\footnotetext{
${ }^{1}$ Oskar Halecki, Un empereur de Byzance à Rome. Vingt ans de travail pour l'Union des Églises et pour l'Émpire d'Orient, 1355-1375, Warzawa, 1930, p. 43.
} 
patriarch of Constantinople should be considered, who, although only by his name, was keeping awake the Byzantine pain and Papal and Western attitude towards the Byzantines. In the same time, the real holders of the temporal and spiritual power in Constantinople, were called by the papal correspondence imperator, respectively patriarch graecorum. As usual, the discussions took place between the emperor and Papa, and if the Patriarch Filotei did not take part to the negotiations at all, we should not blame his absence and neither the failure of the imperial unification. Emperor Ioan V Paleologul, tied to the Catholicism by the influence of his mother, Anna de Savoya (regent between 1341-1347), becoming orthodox by marriage to Andronic II Paleologul (1282-1328), but deceased Catholic nun ${ }^{2}$, showed himself a sincere and steadfast follower of the union with Rome since his first project, dated 15 December 1355, remained secret, by which he committed to remaining faithful and submissive to Pope Inocentiu VI and to his successors, promising the continual endeavor that his submissives would do the same.

The successor to the throne, Andronic III Paleologul (13281341), was trained in Latin culture, three Latin colleges were opened in Constantinople, the children of the nobles were encouraged to receive latin education, a papal legate permanently benefited a palace and a beautiful church in the capital. If the Emperor did not respect his obligations, the imperial power should have been passed to the despot Manuel, who would have been sent to the Pope as a hostage, and the Pope as a spiritual parent would take charge of the Empire until its full age. For himself, Ioan $\mathrm{V}$ also demanded that he had been given the supreme dictate over the Christian armies that would take part to the crusade ${ }^{3}$. The Pope did not appear as exigent as the Emperor

${ }^{2}$ Ibidem, pp. 31-59; J. Smet, The Life of Saint Peter Thomas by Philippe de Méziéres, Rome, 1954, pp. 64-83; Nicolae Iorga, Philippe de Méziéres (13271405) et la croisade au XIV siècle, Paris, 1896, pp. 135-138.

3 Jean Meyendorff, „Jean-Joasaph Cantacuzène et le projet de concile oecuménique en 1367," în „Akten des XI Internationalen Byzantinischen Kongress”, München, 1958, pp. 363-369; Idem, „Projets de concile oecuménique en 1367. Un dialogue inédit entre Jean Cantacuzène et le légat Paul”, în „Dumbarton Oaks Papers”, XIV, 1960, pp. 149-177; Donald M. Nicol, 


\section{Patriarch Filotei I Kokkinos and the Western Church}

pretended, proving himself more realistic, especially as he knew the position of the Church and the Patriarch, to whom he was seeking to win to the unification, he received no answer from the intransigent Calist I (1350-1353; 1355-1363), so that everything remained just a simple plan. Filotei I returning to the patriarchate did not take part to the unification talks for several reasons, but he maintained his position of the Orthodox always, position which, moreover, Ioan VI Cantacuzino always supported, that the union of the Churches cannot be done by a political act, but ony by an ecumenical Synod ${ }^{4}$, and in 1367 it was clearly raised the question of convening such a council. In the manifestation of Ioan VI of Cantacuzino as a hesychasts and his constant preoccupation for the church union, no contradiction should be seen, because the hesychasts were not all fierce anti-Latins, but they were fighting the political unionism, but based on a religious compromise.

In this way was also Filotei I, who from this point of view could have been regarded as less intransigent than his forerunner, having an objective intransigence, that the religious unification should not be reduced to a simple political calculation. The union, according to the views of the emperor and the unionist party, was rather shaky in both conception and reality.

If Filotei I shared other views, he should not be judged as a patriotic evil, because he watched the things from the position of the Ecumenical Patriarch and of the Universal Orthodoxy. But only a small part of Orthodoxy was located between the boundaries of the Byzantine state. If he identified himself with the emperor, Filotei I would have behaved as a certain Byzantine, and then he would have lost his prestige, and such a large Orthodoxy would have challenged his authority. If the Emperor was in theory of the Romans and, in fact, of the Greeks in these times, then the patriarch was of the Orthodox from everywhere, this means that it was

„Byzantine Requests for an Ecumenical Council in the Fourteenth Century”, în „Annuarium Historiae Conciliorum”, I, 1969, pp. 69-95.

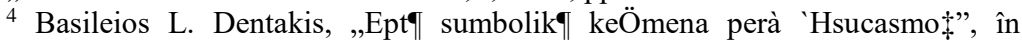
„Episthmonikæ Epethràj Qeologikij Scolhj tou Panepist'mion 'Aqhnwn”, t. 22, 1975 , p. 727. 
ecumenical. Filothei's attitude of resistance to the Latinization tendency of the Byzantine unionist party can not be regarded as the pride of hesychast origin. Here we must see the rejection of a tactic of undermining the Orthodoxy through desertion, forcing the church leaders to come to unity of need, as a natural return of the lost herd to the motherly Church of Rome by detouring the clarification of the doctrinal differences. If for the emperor who had secretly promised the rejection of Orthodoxy or for his minister Demetrios Kydones (1324-1398), who had secretly been catholicized in $1360^{5}$ or $1363^{6}$ and others like them, the doctrinal problems were secondary and they regarded the state as statemen, the Patriarch was not allowed to do this.

The patriarch's silence must also be seen as a desire not to stop the efforts to rescue the Empire, even if he was convinced that it could not be as the Emperor or the Pope wants, but it must be remembered the fact that Filotei I identified himself with the views of Ioan VI Cantacuzino and by this he was no stranger to any talks or concrete actions of union with Rome. By giving up political responsibility, the former Emperor gained greater moral authority and greater popularity than during the time of power.

Filotei I calls him the "divine counselor" of his son-in-law. Although they served the same purpose, their views were different. Ioan V Paleologul strongly sought the western support against the Turks whose vassal arrived and saw in Orthodoxy a hindrance to the rescue of the Empire. On the other hand, old Ioan Cantacuzino turned inward, being a subtle, learned, broad-minded theologian and the most capable politician of his age, who supported the Byzantine clergy, led by the patriarch Filotei I and most Byzantines, was emboding faithfulness to Orthodoxy, and was not unrealistic in treating the union of Churches as his imperial son-in-law did. If Ioan of Cantacuzino had patronized the treaties with papal legions, he would have done this with the necessary ideological erudition, especially because he had also initiated in western theological thought, and in his environment

5 Jean Meyendorff, Initiation à la théologie byzantine, Paris, Les Éditions du Cerf, 1975, p. 143

${ }^{6}$ Ibidem, pp. 140-144. 


\section{Patriarch Filotei I Kokkinos and the Western Church}

were made the translations into Latin ${ }^{7}$. Of the many moments of the union talks, we are more interested in those of 1367, when Filotei was involved in a certain way. After the useless journey to Buda and the humbly humiliation from the emperor in Vidin ${ }^{8}$, he still had a bitter experience in his hopes from the West, but he did not see another way. Only his German cousin, Count Amedeo VI of Savoya (1343-1383), had been of a real help when, in August 1366, pulling the fortress of Gallipoli from the Turks, he returned it to Byzantium, then obtained from the Bulgarians the right to pass to Constantinople. And when, after other concrete evidence of the affection for Byzantium and Emperor, Amedeo de Savoia accompanied at Constantinople in 1367 the Papal legate Paul, in the union negotiations, the hopes of the Byzantines who still believed in the salvation from Rome became even bigger. This Paul, who had been a member of Simisso for many years, then Archbishop of Teba, and only from April 17, 1366, the Latin patriarch of Constantinople, serving the struggles of union, inspired confidence, but only to the pro-Latin Byzantines.

The bound of Pope tried to begin negotiations for the union of the Churches as usual, with the Emperor, but he was forgiven because he had first to refer to with Ioan-Ioasaf Cantacuzino, the Patriarch and the Synod ${ }^{9}$, which had happened. The Patriarchs of Alexandria and Jerusalem participated in this consulting of the Emperor, and the answer of three patriarchs and several synods was that the matter must be resolved by convening an ecumenical Synod $^{10}$. Meanwhile, the bound of Pope wanted to talk with the Patriarch of Filotei I, but he declined first because Paul was considered a usurper of his chair, but he reasoned that he had no delegation from the Pope, a written mandate, could not officially be received in the presence of the council. In the same time, Flotei

\footnotetext{
${ }^{7}$ Oskar Halecki, op. cit., pp. 111-137.

${ }^{8}$ Jean Meyendorff, Projets de concile oecuménique en 1367, în loc. cit., p. 170.

${ }^{9}$ Fr. Miklosich, Ios. Müller, Acta patriarchatus Constantinopolitani, t. I, p. 491; Jean Darrouzès, Les Regestes des Actes du patriarcat de Constantinople, t. I: Les Actes des patriarches, fasc. V: Les Regestes de 1310 à 1376, Paris, 1977, p. 439. ${ }^{10}$ Jean Meyendorff, art. cit., p. 170.
} 
I stated that he could personally receive Paul in a private and friendly discussion ${ }^{11}$. Offended, the bound of Pope claimed the Patriarchal answer to the unification issue. Meanwhile, the emperor, patriarch and synod gave Ioan-Ioasaf Cantacuzino a mandate to represent them in Paul's conversation. The talks between the papal legate, Paul and Ioan VI of Cantacuzino, took place in June 1367 in the Vlaherne Palace, the Emperor and the Imperial family were present, as well as several civilian dignitaries, and from the Patriarch Filotei I attended three of the most important metropolitans of the Synod, those of Heracleea, Efes, Adrianopl, and other patriarchal dignitaries.

Through the clarity and dignity with which the monk Ioasaf Cantacuzino presented the Orthodox position regarding the union, it seemed that the very patriarch Filotei I would have been speaking. He spoke about church union and overlooked the imperial thought of military aid, and at the indictment he did to non-Christian Catholic methods towards the Orthodox, the papal legate had nothing to answer and had to accept the solutions of the ecumenical Synod that was to be held in Constantinople between June 1367 and May 1369. According to the views of Cantacuzino and Filotei I, the delegates of the five Apostolic Patriarchs should join the Synod: Rome, Constantinople, Alexandria, Antioch, and Jerusalem, Serbian and Bulgarian Churches, Catholicos of Georgia, as well as the autonomous metropolises of the Ecumenical Patriarchate of Russia, Trapezunt and Caucaz.

Once the Orthodox point of view was accepted, Filotei I hurried up to make the invitations to the synod, as we can see from those to the Archbishop of Bulgaria and the Patriarch of Antioch $^{12}$ in May 1367, which have been preserved. And Filotei I did not doubt that the arguments of the Orthodox will overwhelm the Latins ${ }^{13}$ in the discussions of the synod, and they will be

\footnotetext{
${ }^{11}$ Ibidem, pp. 491-493; Oskar Halecki, op. cit., pp. 152-153; Jean Meyendorff, art. cit., pp. 156-161; Jean Darrouzès, op. cit., p. 440.

12 Ibidem, p. 491; Ibidem, p. 441.

${ }^{13}$ Fr. Miklosich, Ios. Müller, op. cit., t. I, p. 492; Jean Darrouzès, op. cit., pp. 439-440.
} 


\section{Patriarch Filotei I Kokkinos and the Western Church}

persuaded how they have already engaged in the negotiations ${ }^{14}$ of the Vlaherne. In addition to the acceptance of the Synod, a great gain was the admission by the Latins of the possible appropriation of Orthodox points of view, in the doctrinal controversies, giving up for a moment, even if only by virtue, at the papal mentality, that church union was possible only by imposing papal supremacy and Catholic doctrine on schismatics. The result of the negotiations from Constantinople should have been brought to the attention of the Pope, and the two papal negotiators, the legate Paul and Count Amedeo de Savoya, left Byzantium, but not alone, but accompanied by a Byzantine delegation of eight people, who had to confirm the decided ones, to prepare all that what was necessary for the synod, and prepare the visit the Emperor would do in Rome.

The Delegation was mixed, from imperial and patriarchal representatives: the parakimenus Teofilact, the imperial ambassador, the Metropolitan Nil and the great chartophylax Teodor, as representatives of the Eastern Patriarchs, the Archimandrite Macarie as the clergyman, the two delegates of Constantinople, Teodor Domesticos Proximos and Constantin Metaxopoulos, unknown, remaining the two representatives of the byzantine nobility. It is worth noting the predominance of ecclesial delegations, who insisted on the necessity of convening the ecumenical Synod. Although the church ambassadors shared Filotei's guidance, the patriarch took care that they appear as delegates of all Eastern Patriarchates in order to make clear the representation of Orthodoxy and not just of the Constantinopolitan Patriarchate, which gave even more weight to the idea of the Ecumenical Synod. Of course, Metropolitan Nil, probably from Milet, then from Sozopolis, was the one who gave Pope the common message that the Patriarchs of Filotei I, Nifon of Alexandria (1366-1385) and Lazar I of Jerusalem (1342-1367) who established the position of Orthodoxy in the question of the

\footnotetext{
${ }^{14}$ Oskar Halecki, op. cit., pp. 164-165; Jean Meyendorff, art. cit., pp. 160-161; Jean Darrouzès, op. cit., p. 441.
} 
unification of the Churches, and which was none other than the convocation of the Ecumenical Synod..$^{15}$

The Pope was put in a position to reconsider his point of view that the Emperor alone can make church's union, since not even the Ecumenical Patriarch could act without the consent of the other Patriarchs. The reception of the Byzantine delegation by Pope Urban V on 7 October 1367 in Viterbo, where the Pope was on his way from Avignon to Rome, was of course reduced to words of courtesy, without deepening the problems, only that it was understood Pope's rejection just of the essential byzantine point, namely the Ecumenical Synod. If it is not known exactly how the talks were conducted, we are clear from the letters of the Pope, dated 6 November 1367, to those who are called to facilitate the imperial efforts for the union, meaning Emperor Elena, the sons Andronic, Manuel and Michael the Paleolog, Demetrios Kydones, Strongillos and John, the prefect of the capital. Without any clarification of the papal conditions and the byzantine promises, the Pope's letters insisted on the religious aspect of the union and were highlighted the political advantages for the Byzantine Empire that would follow from the act of union $^{16}$. No papal word to the patriarch, however, was enough to understand the fall of union hopes.

The Patriarch Filotei I reacted with a firm attitude after a reckless full of expectation, at the council of April 1368, and reprisals against the anti-palatites and against all those who shared the "Latin errors". The Pope preferred the personal conversion of the base to Catholicism to the Synod, and thus the most important fact that followed was the journey of Emperor Ioan V Paleologul to Italy, crowned by the personal abstraction of Orthodoxy and the transition to Roman Catholicism in the Basilica of Saint Peter of Rome, Sunday, October 21, 1369. The Catholicization of the Emperor was strictly personal, and none of

\footnotetext{
${ }^{15}$ Oskar Halecki, op. cit., pp. 160-168, 367-369; Aloysius L. Tăutu, Acta Urbani PP.V. (1362-1370), Roma, Typis Pontificiae Universitatis Gregorianae, 1964, pp. 204-205; Jean Darrouzès, op. cit., p. 441.

${ }^{16}$ Greek and Latin text found in Sp. P. Lambros, în „Neoj Hellenomnenon”, XI, 1914, pp. 241-248.
} 


\section{Patriarch Filotei I Kokkinos and the Western Church}

the imperial suite, neither Andronic nor the dignitaries accompanying him left Orthodoxy, except for Demetrios Kydones who had gone to catholicism years ago. On February 22, 1370, when the Emperor was still a papal guest, Urban V talked to the byzantine and the byzantine clergy, announcing the joy of converting their emperor, promising that when all Greeks oppressed by the Turks followed the example, they could be released, and the idea of the Ecumenical Synod was therefore rejected. Thus, the Byzantines, upon patriarch's advice, broke any negotiations with the papacy ${ }^{17}$, and Filotei I was indeed intransigent in the attitude towards the union against which he would fight for the defense of Orthodoxy.

The Emperor, who until the conversion was magnificus vir Iohannes Paleologus, imperator Graecorum illustris, was rewarded by the pontifical chancellor with the title: carissimus in Christo filius noster Iohannes Paleologus, imperator Graecorum illustris ${ }^{18}$, and if we look more closely, it would seem that this was his most important papal reward at which he did not even think about. Poor and more isolated after returning from Rome, Emperor Ioan $\mathrm{V}$ was more compassionate, while the patriarch Filotei I, more powerful, authoritarian and more intransigent, having his own policy, had the power to excommunicate him threatening his throne, and yet he did not do that. Perhaps for mercy, perhaps from consideration for the Cantacuzino, perhaps he did not want to interfere in politics, perhaps because of the desire for personal and general silence, and for many other reasons. And then it was clear that the union with Rome was not a king's whim, but in the exasperated state of Byzantium, especially after the Pope had made so many promises, it would have been an error for Ioan $\mathrm{V}$ not to consider it. Even if he was aware that he was mistaken, he had to bind Rome as the only salvation, and it was not his fault because he was disappointed, not even the Patriarch's fault that he thought of saving the Empire like that.

${ }^{17}$ Oskar Halecki, op. cit., pp. 204-205.

${ }^{18}$ Ibidem, pp. 358, 360, 362, 364-370, 379-380, 382-384. 
Byzantium himself was unable to save himself, and the salvation could only be external, or the Latin and Orthodox Christian papacy and forces that would have been able to help, could not then rise, as so many times in history, over ambitions and small and immediate interests. Ioan V Paleologul struggled as he could, with more or less realism, but it is certain that Rome deceived him, and also the West. The Patriarch Filotei I, in his attitude towards Rome, was wide-awake and opposed his personal action as no other Patriarch in the history of Byzantium.

If the attitude of the Patriarch Filotei I to Rome was contrary to that promoted by Emperor Ioan V Paleologul, as time went on and the detached view of the events of that troubled byzantine age, we find the justice of the patriarchal position and of the Byzantine Church in general. It finally proved to be naive, all of the emperor's hope in the West's military support, and all his efforts in this regard. The emperor's passage to Roman Catholicism proved to be of no help to him and to Byzantium, and Latin support proved to be a vain illusion until the last moments of Byzantium. Even though the popes were sincerely seeking their union to the despair of Constantinople, they could not dispose of the armistice armies to shed their blood for a Christian cause of sentimental significance that could not tempt the Latin sovereigns who had these troops.

The plan to save Byzantium by Western support was a clear illusion, but those who were involved in his accomplishment could not see it. The other patriarchal plan to save Byzantium by military coalitions of the Orthodox peoples could be less utopian if Orthodox principles had the time to convince themselves of their own rescue of Turkish dangers and if they had the necessary time to organize the crusade. But here, too, people saw their immediate and hard-going interest beyond the accumulated animosities and enmities. And the plan of Filotei I was easier to accomplish because the rescue interests were common to the same enemy, he also shared the fate of the rescue by Rome and the Latin troops that Filotei I rejected and had no reason to regret this attitude. 


\section{Steps in organizing an anti-Ottoman coalition of the Orthodox states}

From the resentment towards the papacy and the latins in general, as well as from the belief that church's efforts were vain, since the Pope rejected any thorough discussion and the idea of the Ecumenical Council, the Patriarch Filotei I increasingly in control of the situation, gave up the reserved attitude from the unification negotiations from the summer of 1367 . He decided to have an adversity of any church closeness between Rome and Constantinople, thus being in contradiction with the Emperor's orientation. If we consider the emperor's efforts until then, the humiliations he suffered and the various echoes of Latin resentment towards the Greeks, which were not encouraging at all, the action of the Patriarch Filotei I to co-ordinate the Orthodox rulers in a crusade against the Turkish dangers with the main purpose of the Byzantine rescue, appears fairly realistic. It was another way of saving the Empire, but also of excluding papal supremacy over Orthodoxy.

The Patriarch Filotei I and the monk John-Ioasaf Cantacuzino believed that Byzantium could be saved by Orthodoxy. The closest Orthodox neighbors were the Serbs and the Bulgarians, but there was much adversity between them and Byzantium. For centuries, these neighbors sought to conquer a number of Byzantine territories and often succeeded, and their last confrontations with Byzantium were very recent. Both neighbors have kept their dream of conquering Byzantium. They infriged the title of emperor and even in the church they raised patriarchs either by pulling out the Constantinopolitan agreement, as the Bulgars had done, or by usurpation, that is, selfproclamation, as the Serbs did. Czar Stefan Dusan (1331-1355) brought the Serbian state to the peak of its sphere, mostly on Byzantium, wanted to be emperor, only self-proclamation was not enough, but had to be crowned by the Patriarch. And as the Ecumenical Patriarch was inconceivable to bless the usurpation of the imperial title, which could only belong to the Byzantine, Dusan decided to proclaim patriarch the Serbian archbishop of Peč. 
A synod in Skoplje was convened in the 1346 Palm Sunday, attended by Archbishop Nicolae of Ohrid, an Athos delegation headed by the Protoss, and Bulgarian Patriarch Simeon of Târnovo. Archbishop Ioanichie (1338-1346, patriarch from 1346-1355) was proclaimed "Patriarch of the Serbs and eparchies by the sea" without the consent of the Ecumenical Patriarch, and on Sunday of the Resurrection of the Lord on April 16, 1346, Stefan Dusan could be crowned by his patriarch "Emperor and autocrat of Serbia and Romania", his wife Elena, queen, and his son, Uroş, king. Although he did not recognize the new patriarchate, Constantinople did not respond with anathema until 1352-1353, when the Serbs drove the Greek bishops from the conquered byzantine territories, and so Patriarch Calist I anathematized Czar Stefan Dusan and the Serbian Church, which disturbed even more deeply the Byzantine-Serbian ties ${ }^{19}$. Nonetheless, Patriarch Calist I, later sought to approach the Serbs and died in Serrhes, where he came to win the Dusan widow he had anathematized for that purpose. Filotei was in The Athos when Dushan took possession of the Holy Place and knew the Serbian privileges and gifts, as well as the unexpected gesture that Dushan demanded from the aghiorians to mention him in prayer, and found it appropriate that the name of the byzantine emperor should be mentioned before his own. ${ }^{20}$ The premature death of Czar Stefan Dusan on December 20, 1354, was received with reasonable relief from Byzantium, because his glory had cost territories and had greatly damaged byzantine pride.

In Serbia, weakened and divided, Byzantium no longer saw a danger and understood that Serbs could even become allies. The ties between Byzantium and the Serbian principality of Șercheș, led by queen Elena Elisabeta Dusan (1355-1365), were established, and under the despot Ioan Uglieşa (1365-1371), these ties

\footnotetext{
19 Paul Lemerle, Philippes et la Macédoine orientale à l'époque chrétienne et byzantine, Paris, 1945, pp. 198-213; George C. Soulis, „Byzantino-Serbian Relations", în loc. cit., pp. 57-61; I. Tarnanidis, 'IstorÖa tij Serbikij 'EkklhsÖaj, ed. a II-a, Thessaloniki, 1982, pp. 53-55.

${ }^{20}$ See George C. Soulis, „Tsar Stephen Dusan and Mount Athos”, în „Harvard Slavic Studies”, t. II, Cambridge, Mass., 1954, pp. 125-129.
} 


\section{Patriarch Filotei I Kokkinos and the Western Church}

strengthened. Regarding the church, the relations between Șercheș and the Metropolitan of Thessalonic were tightened ${ }^{21}$. And if we remember that Athos was under serbian political rule, but under byzantine spiritual authority, there was still a meeting point and approchement between the byzantines and the serbs in enmity, but who had begun to look for fear of the Turkish common danger. Besides Orthodoxy that would urge reconciliation, there was also the hesychasm, as the serbian church was led by the hesycasts ${ }^{22}$, but the turkish dangers had reminded the serbs about these common points with Byzantium, whose weakness also contributed considerably. After the serbs tried to unite with Rome in the last years of Dusan, they began to appreciate the Orthodoxy which the Patriarch Filotei I wanted to unite against the ever more serious turkish threat to Byzantium and the balkan orthodox nations. The rejection by Pope Urban V of the Ecumenical Synod projected in the negotiations from Vlaherne in June 1367, led Filotei to antiLatin doctrinal intransigence and to the rush of the idea of uniting the orthodox forces in a crusade. Ioan Uglieşa, who manifesed himself as a sovereign in his principality, had met the patriarchal plan, and if until now the talks had been shrouded in mystery, the closeness had begun to materialize.

After the talks from 1367 over the ecumenical Synod project, Filotei I sent a delegation headed by the Metropolitan Teofan of Nicey to Serrhes to deal with Ugliesa to find a way to resolve the disputes, and the reply would have been brought to Constantinople by the serbian sovereign's messengers the next spring. It was the despot Ugliesa who returned to the Ecumenical Patriarch all churches, metropolises, and any patriarchal rights in

\footnotetext{
${ }^{21}$ See Georges Ostrogorsky, „Problèmes des relations byzantino-serbes au XIV siècle”, în „Proceedings of the XIII ${ }^{\text {th }}$ International Congres of Byzantine Studies", London, 1967, pp. 43-54.

${ }^{22}$ Miloje M. Vasic, „L'hésychame dans l'Église et l'Art des Serbes”, în vol. L'art byzantin chez les slaves. Les Balkans, dédié à la mémoire de Theodore Uspensky, Paris, 1930, pp. 110-114.
} 
exchange for the recognition of Serbian temporal ${ }^{23}$ power in March 1368. What Patriarch Calist I tried to obtain from Dusan's ${ }^{24}$ widow was accomplished under Filotei I and Uglieza. The achievement was great and brought closer the patriarchal Byzantium, because with the imperial one it was hard to find compromises, because of the territorial differences but also because of an expensive byzantine principle, namely the usurpation by the serbs of the title of emperor and even of "Romania", despite the connection between the two imperial families $^{25}$. The titles taken by these descendants who shared the inheritance of Stephen Dusan, the Greek language used in their churches, the byzantine imperial names as a result of the affiliations, the byzantine noble titles, all this byzantine ambience from the serbian Courts meant a tendency to ennoble these principles, but also legitimacy of the claims of natural successors of Byzantium, which Constantinople could not accept.

The Byzantine emperor's journey to Rome gave Filotei I the opportunity to deepen his closeness to Ioan Uglieşa in conflict with his father, Stefan Uros. The Patriarch tactfully acted to the reunification of the metropolis, keeping the serbian hierarchs and ordaining the Greeks for the vacant seats in May 1371, willing to prevent any future breach of the metropolis recovered from the

${ }^{23}$ Fr. Miklosich, Ios. Müller, op. cit., t. I, pp. 560-564; Giovanni Mercati, op. cit., pp. 320-322; I. Tarnanidis, op. cit., pp. 135-137; Jean Darrouzès, op. cit., p. 448.

24 Ion Iufu, „Scurtă istorie a Bisericii Ortodoxe Sârbe”, în „Biserica Ortodoxă Română”, anul LXXV, 1957, nr. 8-9 (august-septembrie), p. 776.

25 Ştefan Duşan semna greceşte: „Stöfanoj ôn Cristó tó QeÓ pist’j basilesj kaà a ̈̈tokr£twr SerbÖaj kaà 'RwmanÖaj”, iar în sârbeşte „Stefan v Christa Boga verni car Srblien i Srkom" după ce fiul său Ştefan Uroș s-a căsătorit cu sora împăratului Ioan al V-lea Paleologul, în anul 1343. Fratele său vitreg, Simeon Uroş, a cărui mamă era o Paleologhină, stăpânind la Tricale, între anii 13551371, se intitula: „Sumê̂n ôn Cristó tó QeÓ pist’j basilesj kaà aŸtokr£twj RwmanÖwn kaà SerbÓn - Palaiol "goj” sau şi cu adaosul ,kaà pant'j 'Alb£noł Orresij - Palaiol "goj”. În acelaşi timp, Ioan Uglieșa, semna: „'Iw£nnhj ôn CristÓ tÓ QeÓ pist’j desp “thj kaà a Ÿtokr£twr - Ö̈glöuj”. Ginerele lui Simeon, ca despot al Epirului semna: „Qwm Cj desp “thj Komnhn'j - Palaiol“goj”. A se vedea Paul Lemerle, op. cit., p. 204; Georges Ostrogorsky, „Étienne Dusan et la noblesse 


\section{Patriarch Filotei I Kokkinos and the Western Church}

ecumenical seat. The Patriarch threatened with excomunication the clergy and with anathema the laity who will dare to do so. And the words of patriarchal appreciation for the serbian despot, wise man, good and fearful of $\operatorname{God}^{26}$, were no longer just mere protocol formulas. The success of the patriarch's reconciliation with the serbs at Serrhes gave courage to go further. Thus, Ioan Uglieşa proposed the Byzantine emperor the alliance against the turks, also strengthened by the new matrimonial ties of the two dynasties, offering the Empire both impoverished and monetary subsidies. Now Filotei could prove that the military and money support from serbs was much more concrete than the papal promises with which the Emperor returned from Rome.

To these personal offers, Ioan Uglieşa also added the alliance of his mighty brother, King Vukaşin, as well as the princes Balcha from Zeta. Thus, the Patriarch Filotei I succeeded that Serbia made by Stefan Dusan, offer Byzantium the precious alliance he needed. The exception was made by the territory occupied by Stefan Uros, who called himself the autocrat of Serbia and Romania, whom the disagreements he had with Ioan Uglieşa especially kept him away from this alliance. At about the same time with the serbian ambassadors, also came to Byzantium a humiliating peace proposal of Sultan Murad. Prepared to destroy the serbs, the turks were trying to restitute the strategic city of Gallipoli.

The Emperor was in a great dilemma and unable to respond clearly to turkish claims through acceptance or refusal. His proLatin policy did not bring him the military support he needed, and in the Balkan alliance he had not committed himself. The unionist party on which the Emperor was based had rejected for a while the plan of "Orthodox opposition" of ignoring the turks without the help of the West and therefore without the condition of unification. Union fighter Demetrios Kydones had come to

serbe dans la lutte contre Byzance”, în „Byzantion”, XXII, 1952, pp. 151-157; George C. Soulis, „Byzantino-Serbian Relations”, in „Proceedings of the XIII ${ }^{\text {th }}$ International Congres of Byzantine Studies", London, 1967, pp. 60-61.

${ }^{26}$ Fr. Miklosich, Ios. Müller, op. cit., t. I, pp. 553-555; Jean Darrouzès, op. cit., pp. 514-515. 
declare that the Balkan aid must be rejected at all costs, precisely because of the considerable forces that had to be triggered by the conflicts of the byzantine-serbian-bulgarian centuries. They deepened hatred and mutual mistrust, and while the patriarch was at the head of those who believed that orthodoxy and the hesychasm can overcome multi-secular adversity, Demetrios Kydones, the leader of the unionists, saw the Balkan alliance even dangerous to the interests of Byzantium. ${ }^{27}$

It is well known that Patriarch Calist I had tried to reconcile with the serbs at Serrhes where he was going to make the most telling gesture in this respect. Less should be seen the command of Emperor Ioan V Paleologul that the patriarch should go to Serrhes, which could easily be interpreted as a great byzantine humiliation, equivalent to the next humiliating imperial travel to Buda and Rome. Of course, the emperor agreed to the patriarch's attempt, which also appeared as a pastoral visit to the territories abducted by his jurisdiction and which he wanted to regain. Faced with all the attention to the West, the Emperor was somehow indifferent to these church trials, which, if were successful, the beneficiary woul also have been the Byzantium, and to oppose it clearly he could hardly do so with a strong Church and an authoritarian Patriarch Such as Calist I, who obviously did not pursue any personal benefit, but all the byzantine interests.

The Patriarch Filotei I successfully continued his approach to the serbs until the possibility of the military alliance and the money supply for Byzantium who was so strained military and financial. Reaching this result with the serbs could have given hope that also Czar Stefan Uros would be drawn into an alliance in any future, if turkish danger had not been precipitateIn the same time, the Patriarch Filotei I also strived to attract bulgarians to the planned crusade, but here the difficulties were greater. The byzantine-bulgarian ties were not traditionally good, and the bulgarians, with the long reign of Czar Ivan Alexandru (13311371) in Târnovo, called "emperor of the bulgarians and the greeks", had become disunited and did not have one powerful driving center. Byzantium took advantage of the

${ }^{27}$ Oskar Halecki, op. cit., pp. 143-144. 


\section{Patriarch Filotei I Kokkinos and the Western Church}

Bulgarians'weakness and imposed a tribute on them and also regained their territory in 1364, either directly or through the army of Count Amedeo VI by Savoya, a little later. The same Amedeo had to intervene for the removal of the byzantine Emperor, his cousin, from the humiliation received in Vidin by the Bulgarian Czar Ivan Stracimir (1360-1396) at the return of the Paleolog in 1367 from the humiliating and unnecessary journey to Hungary . Neither the byzantine-bulgarian church relations were not good, since Constantinople, although recognized the bulgarian Patriarchate as early as 1235 , did not count it equal to the others. Thus, the Patriarch of Târnovo, not being considered equal, was not included in the diptych. An evidence that Byzantium honored the title of the Bulgarian patriarch was also the condition that he should receive the Holy Chrism from Constantinople. But the bulgarians, in order to evade this sign of obedience, did not ask the Holy Chrism, but they did not dare to sanctify it, but they used the chrism that flowed from some relics of saints. ${ }^{28}$

If the Byzantine-Bulgarian political relations were tense and the patriarchal church relations were not good, there were still people who thought of finding a way of understanding between the two orthodox nations to stop the Turkish dangers. An example is that offered by the venerable Teodosie, abbot of the Kilifar monastery, which he himself founded in the year 1350. Teodosie was respected and was formed as an apprentice of St. Grigorie Sinaitul. Of course, he knew Greek and had ancient ties with byzantine theologians and byzantines hesychasts, among them probably Patriarch Calist I, from the time when both were Sinai's disciples. Teodosie, understanding the increasing turkish dangers, went to Constantinople in 1363, accompanied by four disciples. The purpose of his trip was to advise Patriarch Calist I on the possibility of saving the balkan orthodox nations from the invasion of

${ }^{28}$ Émile Turdeanu, La littérature bulgare $d u$ XIV siècle et sa diffusion dans les Pays roumains, Paris, 1947, pp. 1-4; 38-41, Hrisostom Papadopoulos, ' $H$ 'EkklhsÖa tij BoulgarÖaj (865-1938), Atena, 1957, p. 47; Epifanie Norocel, „Patriarhia Bulgară de Târnovo între anii 1235-1293”, în „Studii Teologice”, anul XVIII, 1966, nr. 3-4 (martie-aprilie), pp. 152-154. 
the turks ${ }^{29}$. Most likely, this trip was conducted by bulgarian political and church figures. What he talked with, and whether he did talk to Patriarch Calist I, we do not know anymore, because in that year Calist I went to Serrhes where he died, and the venerable Teodosie also died of a difficult disease in Constantinople, in the Patriarchal Monastery of Saint Mamant. Thus, the first bulgarian thought of understanding with the Byzantines against the Turks was shattered too early, and the subsequent byzantine-bulgarian military conflicts hindered the hopes of closeness.

Among the disciples who accompanied Teodosie to Constantinople was Eftimie, the future and last Patriarch of Tarnovo. After the death of his spiritual father, Eftimie passed to the Studion ${ }^{30}$ monastery, the great byzantine theological center, where he stayed for a year, then to the Peribleptos ${ }^{31}$ monastery, where he left for Athos in 1365. He spent time in several monks athonite, manifested against the union with Rome and had beside him the apprentice Ciprian Tamblac, the future metropolitan of the russians. It is stated that for his anti-latinism Eftimie suffered, but was saved by the intervention of Patriarch Filotei I, who would have received him warmly in Constantinople ${ }^{32}$, from where he returned to Bulgaria. Personalities like Eftimie and Ciprian Tamblac maintained the atmosphere favorable to a byzantine-bulgarian alliance, but they were unable to do so. The Patriarch Filotei I tried to attract the bulgarians in the crusade planned by him and Ioan Cantacuzino, along with the same endeavor towards the serbs. Soon after returning to the patriarchal seat, Filotei I wrote to the bulgarian Czar trying to improve the tension between him and the byzantine emperor, deepened by the last armed confrontation from the same year, 1364, ended favorably for Byzantium ${ }^{33}$. Although he did not receive an

\footnotetext{
${ }^{29}$ Epifanie Norocel, „Sfântul Eftimie, ultimul patriarh de Târnovo şi legăturile lui cu Biserica românească,” în „Biserica Ortodoxă Română”, anul LXXXIV, 1966, nr. 5-6 (mai-iunie), pp. 554-555.

${ }^{30}$ Émile Turdeanu, op. cit., p. 120.

${ }^{31}$ Epifanie Norocel, art. cit., pp. 555-556.

32 Ibidem, pp. 557-558.

${ }^{33}$ Ibidem, pp. 491-493; Jean Darrouzès, Les Regestes des Actes du Patriarcat de Constantinople, t. I: Les Actes des patriarches, fasc V: Les Regestes de 1310 à 1376, pp. 389-390.
} 


\section{Patriarch Filotei I Kokkinos and the Western Church}

answer, he did not give up his plan and after the discussions from June 1367 for the convocation of the ecumenical Synod, he hurried to invite the bulgarian patriarch to the planned synod.

Filotei I insisted that the bulgarian patriarch should come with the bishops under his obedience. At the same time he alluded to the coldness between them and some of them fed it with unfair accusations against him, asking the bulgarian hierarch to ignore such words. With all his endeavor to avoid the synod, Filotei I avoided the use of the patriarchal title, which surprised us because his chancellor did not reject $\mathrm{it}^{34}$. It seems that the ecumenical Patriarch's approach has remained unanswered from the bulgarian side. Probably Filotei I also tried by other emissaries to communicate the plan of the orthodox crusade, but the bulgarians could not be convinced, especially since neither they nor the serbs had very good relations. The detention of the Patriarch of Târnovo at the advance of the ecumenical Patriarch is easily explained by the fact that while Filotei I reached the point of making his own policy, different from his emperor, who would have missed two years from the Empire, the bulgarian patriarch could not afford to pursue his own policy, even of pure church fellowship, even if he would have sincerely desired it.

Conflicts left deep traces, and the adversity was very big so that, not even the different matrimonial crosses could reconcile these three nations. Only the orthodoxy revived by the hesychasm could awaken them to the reality that only by unification can they overcome the danger that would crush them all. And it was to some extent succeeded in materializing the idea of forgetting any national interest and ambition for the realization of the orthodox crusade. This is also apparent from the fact that the Czar Stracimir tried to depart from the jurisdiction of the patriarch of Târnovo and asked, in 1370, the patriarch of Constantinople to send him a metropolitan for Vidin, his residence and the Patriarch

34 Ibidem, pp. 440, 491-493; Idem, „Ekthésis néa. Manuel des pitakia du XIV siècle”, în „Revue des Études Byzantines”, XXVII, 1969, p. 40. 
Filotei I to reorganize and impose discipline in the metropolitan area of Varna, whose jurisdiction is also exercised over Silistra ${ }^{35}$.

The Orthodox crusade had to include the Romanians who were not in the next neighbourhood with Byzantium, but with the bulgarians and the serbs. Though located further, beyond the Danube, the Romanians did not accept the authority of the Patriarch of Târnovo or that of Pec, and without any restraint recognized the ecumenical Patriarch's jurisdiction. A Greek bishop, Iachint, was transferred from Vicina to Argeş by the patriarch Calist I in 1359, at the request of the Prince of Wallachia, Nicolae Alexandru Basarab (1354-1364). The attraction of the Romanians in the crusade of the Patriarch Filotei I was easy and necessary. The Romanians had the best feelings about Byzantium and their due respect for patriarchal authority and Constantinopolitan imperial prestige, and hostile thoughts about Byzantium could not have. Then Vladislav I (1364-1377) appeared in the eyes of his neighbors as a voivode whose bravery they could find even the genoese in Chilia, the turks themselves, but especially the hungarians in Vidin and the battles for the fortress of Severin. ${ }^{36}$ This meant that Wallachia was considered to be "the main political and military force in the event of anti-Ottoman action".

Although the political factors in Consantinopol and Argeş could have worked together, as their communication channels were not even shady, it could not be done because of political weakness in Constantinople. There, Emperor Ioan $\mathrm{V}$ at the height of these times of Byzantine weakness, believed that if there could still be any rescue for Byzantium, then only from the West could come and not engage at all in the plan of the Balkan Orthodox Alliance. His merit is not to prevent the patriarch's endeavor, either from helplessness or

\footnotetext{
35 Ibidem, pp. 502, 541-550. A se vedea şi Nicolae Iorga, Condiţiile de politică generală în cari s-au întemeiat bisericile româneşti în veacurile $X I V-X V$, Bucureşti, Socec, 1913, extras din „Anuarul Academiei Române. Memoriile Secțiunii Istorice”, seria a II-a, t. XXXV, mem. 12, reedit. în vol. Studii asupra Evului Mediu românesc, ediţie îngrijită de Şerban Papacostea, Bucureşti, Editura Ştiinţifică şi Enciclopedică, 1984, p. 104; Nicolae Constantinescu, Vladislav I, 1364-1377, Bucureşti, Editura Militară, 1979, p. 65; Jean Darrouzès, op. cit., pp. 496, 511-512.

${ }^{36}$ Nicolae Constantinescu, op. cit., pp. 132-142.
} 


\section{Patriarch Filotei I Kokkinos and the Western Church}

from indifference. The Prince of Wallachia's Alliance certainly joined with the equally precious support of Dobrotici, who was always devoted to Emperor Ioan V Paleologul, from whom he received the title of "despot". Moreover, Dobrotici considered himself a vassal of the basilica and even related to it, after 1371, through his daughter's marriage to Michail Paleologul, son of the emperor, who became king of Trapezunt. ${ }^{37}$

Under these conditions it remained established that any byzantine-romanian negotiations should take place under the auspices of Patriarch Filotei I himself. Iachint himself, the Metropolitan of Wallachia became the first confidant of the voivode and the one who had a clear influence on the plans of the ecumenical Patriarchate. Patriarchal messages easily reached Arges through the dynasty of the Great Church, the dicheophylax Daniil Critopulos, or even more easily through the great confidence of the abbot Hariton of the Cuthlumusiu monastery. In 1370, the Patriarchy strengthened the position in Wallachia by imposing dicheophylax as the second metropolitan. But, on the so frequent journeys in Wallachia, seven in number to one time, even if he came to collect aids, certainly brought secret messages to the Romanian voivode in connection with the Orthodox crusade. For the same purpose, Vladislav I would receive a message from the despot Stefan Uglieşa. The Romanian Voivode was probably also asked for the alliance of his brother-in-law, the Serbian Czar Stefan Uros and the Bulgarian Ivan Alexander with his two sons Şişman, the Czar of Târnovo and Stracimir, the Czar of Vidin, whose mother was the daughter Basarab I, therefore, aunt Vladislav I. Stracimir himself was married to a Romanian, and the Romanian voivode struggled to contribute to the antiottoman coalition as required by the ecumenical Patriarch and Serb despot Serrhes. Things were on the right track, and Vladislav I's contribution should be seen as precious.

37 M. M. Alexandrescu Dersca-Bulgaru, „La seigneurie de Dobrotici, fief de Byzance", în Actes du XIV Congrès des Études Byzantines, publiès par les soins de Mihai Berza et Eugen Stănescu, vol. II, București, Editura Academiei Republicii Socialiste România, 1975, pp. 13-20. 
The spirits developed in the sense of the planned crusade of the Patriarch Filotei I until the unionist party of Constantinople considered this option for the rejection of the Turkish dangers. The Unionist leader himself, Demetrios Kydones, a fierce opponent of the Patriarch Filotei I and his policy of uniting the balkan forces, who in the summer of 1366 exposed his exclusively pro-latin political orientation, was in the summer of 1371 in the position of rejecting the dangerous proposal of Sultan Murad and the Balkan military alliance ${ }^{38}$. Kydones' attitude coincided with the political orientation promoted by Patriarch Filotei I consistently for years. And if we think that Demetrios Kydones' personal resentment towards the patriarch was at its height in these years, we must conclude that this great personality of time knew how to overcome his own beliefs, leaning against Filotei's political realism. By this attitude, Kydones moved away from the basil which, barely returned with the bare hands from the West, could not yet decide how to proceed.

Sultan Murad's peace offer to Byzantium was tempting for the moment, but very dangerous for the future, and Filotei I with his collaborators, as well as other deep spirits as Kydones, understood this. The ordinary man who was Emperor Ioan V Paleologul did not have the courage to see the evolution of the events further, and because he had to choose clearly between peace and war, the Emperor wanted not to provoke the turks, but he also hoped the West would materialize the promises. However, it was difficult for him to suddenly embrace action he had rejected or ignored for years, and he wanted to delay the decision. But the turks have rushed the events and left no time for the balkan orthodox crusade as it was conceived by the Patriarch Filotei I and the others who thought like them, meaning the unification of Byzantines, Serbs, Bulgarians and Romanians. Of course, informed about what was being prepared, the turks did not let these peoples have the time they needed to make the alliance, nor did the ottoman Emperor have the time to take up the military coalition. Murad's troops have crossed over to Europe, because the Byzantine did not dare to try to impede Gallipoli.

${ }^{38}$ Oskar Halecki, op. cit., pp. 242-246. 


\section{Patriarch Filotei I Kokkinos and the Western Church}

On September 26, 1371, took place the historic Battle of Cirmen on the Mariţa River, where the Christian coalition was composed only of the serbian armies of the despot Ioan Uglieşa and King Vukaşin, from the Romanian contingents sent by Vladislav I ${ }^{39}$ and probably some help from the Czar Bulgarian Ioan Stracimir. The christian armies were caught by one of the Sultan Murad's commanders during the night and completely destroyed. There, heroic failed the leaders of the serbs, brothers Uglieşa and Vukaşin. With this defeat of christians, the gates of the Balkan Peninsula were widely opened for the ottoman armies, and the turkish chronicles would for centuries be proud. "Allah has made great horror in the hearts of the ghouls. The ghouls unworthy of praise, scaring in the darkness and the darkness of the night, and terrifying were scattered. Some of them were made prisoners, and others fell prey to victorious swords. ${ }^{40}$ The christians had reasons to be dismayed after the unfortunate battle of Cirmen, and in 1372 Pope Grigorie XI (1370-1378) remembered King Ludwig I of Hungary (1342-1382) "with much sorrow of our heart" that "the unbelievers the turks, the enemies of the holy christian name, have won a great victory against some magnates and peoples from the sides of Greece, Wallachia and Serbia. ${ }^{41}$

After the battle from Cirmen, Sultan Murad called on the emirates and achings from the whole Minor Asia by promising them prey and lands on the Balkan Peninsula. These primitive bands rushed to respond to the call, and throwing themselves over the whole peninsula, they devastated everything in their way. ${ }^{42}$ Christians, however, could still not confederate. The new bulgarian Czar of Târnovo, Ioan Şişman (1371-1393), seeing that the defeat of the serbs could not stop the advance of the turks, allied with the serbs led by Prince Lazar (1371-1389), but this

\footnotetext{
39 *** Istoria României, vol. 2, Bucureşti, Editura Academiei Republicii Populare Române, 1962, p. 350. A se vedea şi Aurel Decei, Istoria Imperiului Otoman până la 1656, Bucureşti, Editura Ştiinţifică şi Enciclopedică, 1978, pp. 50-51.

${ }^{40}$ Nicolae Constantinescu, op. cit., pp. 133-134.

${ }^{41}$ Ibidem, p. 134.

42 *** Istoria României, vol. 2, p. 351.
} 
alliance came too late. Both allies soon had to recognize the suzerainty of the sultan against whom they had just united, and Ioan Sisman continued his father's policy of hostility towards the state formations led by Ioan Stracimir and Dobrotici. The byzantine Emperor Ioan V Paleologul believed he could enjoy the christian defeat from Cirmen, since the serbs crushed by the turks led by Radji Ulbeg could no longer opose serious resistance. Thus, at the beginning of November 1371, the despot of Thessalonica, Manuel Paleologul, the Emperor's favorite son, without any difficulty repaired the Serrhes prince of Ioan Uglieşa, a territory abducted by Byzantium by Dusan ${ }^{43}$. It would be a moment of victory, because in the summer of 1372 , very shortly after Cirmen, from the four nations involved in the planned orthodox crusade of the Patriarch Filotei I, only the voivods of Vladislav I remained standing and were not turned into vassals of Sultan Murad I.

Regarding the Patriarch Filotei I, after his plan for rejecting the turks failed and he was convinced again of the West's indifference to Byzantium, he remained constant in adversity to Rome. If the political people were devastated by Cirmen, the Patriarch Filotei I remained faithful to his plan of uniting the orthodox forces and continued his efforts in this direction. Because in Wallachia he could have full confidence in political and ecclesial factors, the Patriarch continued to achieve the church reconciliation with the patriarchs of Peč and Târnovo. Of course, it was considered that church peace, meaning a restoration of Byzantine ecclesiastical authority over the Balkan Orthodox world, could achieve the much-desired military coalition. Already a promising step was made by the approchement between the serbian prince Lazar and Czar Ioan Şişman from Târnovo.

The Voivode of Wallachia was in good relations with Czar Ioan Stracimir from Vidin, as well as with Dobrotici. The hesycasts who had come to the church leadership of the peoples concerned were successfully preparing the religious reconciliation and pan-

43 Oskar Halecki, op. cit., pp. 241-248; Dimitri A. Zakythinos, „Démètrius Cydonès et l'entente balkanique au XIV e siècle", în vol. La Grecs et les Balkans, Athènes, 1948, pp. 44-56, Louis Bréhier, op. cit., pp. 371-375. 


\section{Patriarch Filotei I Kokkinos and the Western Church}

orthodox collaboration on the military realm, meaning they were the promoters of the political hesycasm of the Patriarch Filotei I. Since Czar Ioan Stracimir had detached from the bulgarian Patriarch's authority and passed under the ecumenical Patriarch, and Dobrotici's despot was clearly under Constantinopolitan obedience, only the Patriarch of Târnovo remained in schism more because of the Târnovian Czar. As Ioan Shishman understood that he was forgiving any resentment and ambition in the face of the pagan danger by reaching out to the alliance with the serbs, he returned to better feelings towards Constantinople. And in 1375, by the arrival of Patriarch of Târnovo, Eftimie, the man who lived in the byzantine environment and was spiritually linked to the Patriarch Filotei I, the canonical ties between the bulgarian Patriarchate and the ecumenical Patriarchate were restored. The Patriarchs crossed each other in diptych, and the typical of the Liturgy made by the Patriarch Filotei I was translated into bulgarian by Patriarch Eftimie himself, who also imposed it in his Church. ${ }^{44}$

After the serbian disaster from Cirmen, soon followed by the death of Czar Stefan Uros, Serbia was led by Prince Lazarus, a godly, learned and good patriot, who set out to restore the serbian political and church brilliance. The Patriarch Filotei I continued his plan, and after efforts still unclear enough he reached an agreement with the sovereign and the serbian Church. It is certain that the understanding was through the Athos, and the leadership of the reconciliation mission had the Isaia's abbot of the Hilandar monastery. Besides Isaia, an important participant in these negotiations in Constantinople was the serbian monk Nicodim, the reorganizer of monasticism in Wallachia and who remained known as St. Nicodim from Tismana. It is believed that for his special qualities, Nicodim was distinguished by the Patriarch Filotei I with the rank of Archimandrite, a rank that his successors would have inherited at the auspices of the Tismana monastery.

44 Anthony-Emil N. Tachiaos, 'Epidr£seij tof 'Hsucasmoł eÑj toen ôkklhsiastikeen politikcen ôn 'RosÖa, 1328-1406, Thessaloniki, 1962, p. 99; Epifanie Norocel, art. cit., pp. 559-562. 
Although the church reconciliation between Constantinople and Peč was desired by the Patriarch Filotei I and by the serbian sovereign Lazar, it was delayed by the position of serbian Patriarch Sava IV. In this situation, Lazarus asked monk Nicodemus to persuade Patriarch Sava of the necessity of the act of lifting the schism. Only after the consent of the patriarch, Isaia and Nicodim went to Constantinople, where they were received with great goodwill by Emperor Ioan V and Patriarch Filotei I. The treatises were successful. The anathema of Patriarch Calist I was lifted by Filotei I in 1373, while the serbian Church was headed by Patriarch Efrem. The ceremony of the schism's lifting took place at the monastery of the Archangels of Prizren, at the grave of Czar Dusan ${ }^{45}$, and of course attended by a Byzantine delegation sent by the Patriarch Filotei I, serbian patriarch Efrem, prince Lazarus, a delegation of Athos, Isaia and Nicodim, and most probably delegates from the Patriarchate of Târnovo. It is still not clear how this reconciliation was made and whether the serbian patriarchal rank was recognized by Constantinople $e^{46}$ because the act of recognition was lost. The Ecumenical Patriarchy proceeded with the Patriarchate of Peč, as it was once with the Târnovo, from the need of such a much-needed peace, all inclined towards reality. The serbian prime minister acknowledged the right to order metropolitans and was tolerated to use his patriarchal title, while the Constantinople ${ }^{47}$ chancellery used only the title of "Archbishopric of Peč and of all Serbia". ${ }^{48}$

45 Tit Simedrea, Viaţa şi traiul Sfântului Nifon, patriarhul Constantinopolului. Introducere şi text, Bucureşti, Tipografia Cărţilor Bisericeşti, 1937, pp. 26, 30; Emil Lăzărescu, „Nicodim de la Tismana şi rolul său în cultura veche românească (până la 1385)”, în „Romanoslavica”, seria Istorie, XI, 1963, pp. 267-270.

${ }^{45}$ Ion Iufu, art. cit., p. 776.

46 Tit Simedrea, Viaţa şi traiul Sfântului Nifon, patriarhul Constantinopolului. Introducere şi text, Bucureşti, Tipografia Cărţilor Bisericeşti, 1937, pp. 26, 30; Emil Lăzărescu, „Nicodim de la Tismana şi rolul său în cultura veche românească (până la 1385)”, în „Romanoslavica”, seria Istorie, XI, 1963, pp. 267-270.

${ }^{46}$ Ion Iufu, art. cit., p. 776.

47 Michel Lascaris, „Le patriarcat de Peč a-t-il été reconnu par l'Église de Constantinople en 1375 ?", în Mélanges Charles Diehl, t. I, Paris, 1930, pp. 171- 


\section{Patriarch Filotei I Kokkinos and the Western Church}

Thus, with mutual tolerance and compromises, the Patriarch Filotei I was able to achieve the church reconciliation with the bulgarians and the serbs. It was the first step and very important regarding the military alliance that was pursued by all. The political and religious factors of the Romanians, Serbs, and Bulgarians under the auspices of the Patriarch of Constantinople have removed the obstacles to their unification in the antiottoman coalition. But the Byzantine emperor remained in expectation and in the illusion of western aid, but the Patriarch Filotei I and his allies could hope that at the moment the byzantine soldiers would fight bravely against the turks. Parallel to the efforts of the balkan anti-ottoman alliance, the Patriarch Filotei I also acted to attract the russians in the support of orthodoxy. The events that upset the Consulate in 1376, leading to the dethroning of the Emperor Ioan Paleologul, brutally removed the patriarch Filotei I, and also dissipated his grand plan of the anti-ottoman orthodox crusade, which was so close to be done.

\section{Conclusions}

Patriarch Filotei I Kokkinos remains one of the greatest Byzantine names and one of the most brilliant in many manifestations in which he excelled. A man with a thorough and profound theological and laic culture, author of a varied and extensive work, so valuable, living in prayer and holiness, was a hierarch with the responsibility of his affiliation and a peerless authority. Grigorie Palama's permanent supporter, helped and

175; Vitalien Laurent, „L'archevêque de Peč et le titre de patriarche après l'union de 1375”, în „Balcania”, VII, 2, 1944, pp. 303-310; Georges Ostrogorsky, „Byzance, état tributaire de l'Empire turc”, în vol. Zur Byzantinischen Geschichte, Darmstadt, 1973, pp. 235-244; Jean Darrouzès, op. cit., pp. 552-553.

48 Jean Darrouzès, „Ekthésis néa. Manuel des pitakia du XIV siècle”, în „Revue des Études Byzantines”, vol. 27, 1969, nr. 1, p. 40. A se vedea şi Hrisostom Papadopoulos, 'H 'Orq “doxoj anatolika 'EkklhsÖa, Atena, 1954, p. 117, B. N. Stefanidis, 'Ekklhsiastikce 'IstorÖa, ed. a III-a, Atena, 1970, pp. 444-445. 
defended him with sincerity and devotion, both during his lifetime and beyond, being one of those who contributed greatly to the recognition of the merits of the Isaiah's corife and, decisively, to his canonization in 1368.

The philosophical action and thought, prayer and contemplation, the energy to enforce the morals of the clergy, the conscience of Orthodoxy and hellenism, the intransigence towards the church union only for political reasons, the visionary of imposing Church Byzantium as the truly ecumenical force to save the Empire, and others met all in one and this was Filotei Kokkkinos.

\section{References}

1. *** Istoria României, vol. 2, Bucureşti, Editura Academiei Republicii Populare Române, 1962.

2. Constantinescu, Nicolae, Vladislav I, 1364-1377, Bucureşti, Editura Militară, 1979.

3. Darrouzès, Jean, „Ekthésis néa. Manuel des pitakia du XIV siècle”, în „Revue des Études Byzantines”, vol. 27, 1969, nr. 1, pp. 1-127.

4. Darrouzès, Jean, Les Regestes des Actes du patriarcat de Constantinople, t. I: Les Actes des patriarches, fasc. V: Les Regestes de 1310 à 1376, Paris, 1977.

5. Decei, Aurel, Istoria Imperiului Otoman până la 1656, Bucureşti, Editura Ştiinţifică şi Enciclopedică, 1978.

6. Dersca-Bulgaru, M. M. Alexandrescu, „La seigneurie de Dobrotici, fief de Byzance", în Actes du XIV Congrès des Études Byzantines, 6-12 Septembre 1971, publiès par les soins de Mihai Berza et Eugen Stănescu, vol. II, București, Editura Academiei Republicii Socialiste România, 1975, pp. 13-20.

7. Halecki, Oskar, Un empereur de Byzance à Rome. Vingt ans de travail pour l'Union des Églises et pour l'Émpire d'Orient, 1355-1375, Warzawa, 1930.

8. Iorga, Nicolae, Philippe de Méziéres (1327-1405) et la croisade au XIV siècle, Paris, 1896. 


\section{Patriarch Filotei I Kokkinos and the Western Church}

9. Iorga, Nicolae, Conditiile de politică generală în cari $s$ au întemeiat bisericile româneşti în veacurile $X I V-X V$, Bucureşti, Socec, 1913.

10. Iufu, Ion, „Scurtă istorie a Bisericii Ortodoxe Sârbe”, în „Biserica Ortodoxă Română”, anul LXXV, 1957, nr. 8-9 (augustseptembrie), pp. 769-784.

11. Lascaris, Michel, „Le patriarcat de Peč a-t-il été reconnu par l'Église de Constantinople en 1375 ?", în Mélanges Charles Diehl, t. I, Paris, 1930, pp. 171-175.

12. Laurent, Vitalien, „L'archevêque de Peč et le titre de patriarche après l'union de 1375”, în „Balcania”, VII/2, 1944, pp. 303-310.

13. Lăzărescu, Emil, „Nicodim de la Tismana şi rolul său în cultura veche românească (până la 1385)”, în „Romanoslavica”, seria Istorie, XI, 1963, pp. 237-285.

14. Lemerle, Paul, Philippes et la Macédoine orientale à l'époque chrétienne et byzantine, Paris, 1945.

15. Meyendorff, Jean, „Jean-Joasaph Cantacuzène et le projet de concile oecuménique en 1367”, în „Akten des XI Internationalen Byzantinischen Kongress", München, 1958, pp. 363-369.

16. Meyendorff, Jean, „Projets de concile oecuménique en 1367.

Un dialogue inédit entre Jean Cantacuzène et le légat Paul”, în „Dumbarton Oaks Papers”, XIV, 1960, pp. 149-177.

17. Meyendorff, Jean, Initiation à la théologie byzantine, Paris, Les Éditions du Cerf, 1975.

18. Norocel, Epifanie, „Patriarhia Bulgară de Târnovo între anii 1235-1293”, în „Studii Teologice”, anul XVIII, 1966, nr. 3-4 (martie-aprilie), pp. 146-159.

19. Norocel, Epifanie, „Sfântul Eftimie, ultimul patriarh de Târnovo şi legăturile lui cu Biserica românească,” în „Biserica Ortodoxă Română”, anul LXXXIV, 1966, nr. 5-6 (mai-iunie), pp. 552-573.

20. Ostrogorsky, Georges, „Problèmes des relations byzantino-serbes au XIV ${ }^{\mathrm{e}}$ siècle”, în „Proceedings of the XIII ${ }^{\text {th }}$ 
International Congres of Byzantine Studies”, London, 1967, pp. 41-57.

21. Ostrogorsky, Georges, „Byzance, état tributaire de l'Empire turc", în vol. Zur Byzantinischen Geschichte, Darmstadt, 1973, pp. 235-244.

22. Simedrea, Tit, Viaţa şi traiul Sfântului Nifon, patriarhul Constantinopolului. Introducere şi text, Bucureşti, Tipografia Cărţilor Bisericeşti, 1937.

23. Smet, J., The Life of Saint Peter Thomas by Philippe de Méziéres, Rome, 1954.

24. Soulis, George C., „Tsar Stephen Dusan and Mount Athos”, în „Harvard Slavic Studies”, t. II, Cambridge, Mass., 1954, pp. 125-139.

25. Soulis, George C., „Byzantine-Serbian Relations”, în „Proceedings of the XIII ${ }^{\text {th }}$ International Congres of Byzantine Studies", London, 1967, pp. 57-61.

26. Tăutu, Aloysius L., Acta Urbani PP.V. (1362-1370), Roma, Typis Pontificiae Universitatis Gregorianae, 1964.

27. Turdeanu, Émile, La littérature bulgare du XIV siècle et sa diffusion dans les Pays roumains, Paris, 1947.

28. Vasic, Miloje M., „L'hésychame dans l'Église et l'Art des Serbes”, în vol. L'art byzantin chez les slaves. Les Balkans, dédié à la mémoire de Theodore Uspensky, Paris, 1930, pp. 110123.

29. Zakythinos, Dimitri A., „Démètrius Cydonès et l'entente balkanique au XIV ${ }^{\mathrm{e}}$ siècle", în vol. La Grecs et les Balkans, Athènes, 1948, pp. 44-56. 